\title{
EFEKTIVITAS PENGARUH TEKNIK RELAKSASI DAN COUNTERPRESSURE TERHADAP PENURUNAN INTENSITAS NYERI SELAMA PERSALINAN KALA I DI KLINIK NURSANI KECAMATAN SIGUMPAR KABUPATEN TOBA SAMOSIR TAHUN 2020
}

\author{
Melva Manurung, Erita Saragih, Rachel Natalia \\ Program Studi D-III Keperawatan, STIKes Arjuna \\ E-mail: manurungmelva275@gmail.com
}

\begin{abstract}
Pain during labor differs from other types of pain because it is part of the normal process that is experienced during childbirth. Women have time to prepare and limit their own pain. To manage pain, pharmacological and nonpharmacological management are used. Pharmacological action is still conflicting because the administration of drugs during labor can cross the placental barrier so that it can affect the baby. Therefore, a non-pharmacological method of controlling pain is very important, this method can help overcome pain and does not harm the mother or fetus, does not delay labor if adequate pain control is provided, and does not have allergic effects and drug effects. This study aims to analyze the effectiveness of the technique. relaxation and counterpressure to reduce pain intensity during first stage labor at the Nursani Clinic, Sigumpar District, Toba Samosir Regency in 2020. The design used in this study was the design used in this study was a quasy experimental type One group pretest-posttest consisting of 3 groups and each -Each group was given different interventions, the population in this study were mothers who gave birth to stage I with vaginal delivery at the Nursani Clinic, Sigumpar District, Toba Samosir Regency using accidental sampling. The instrument used was a questionnaire of demographic data and maternal pain intensity based on the pain intensity scale before and after the intervention significantly differed $(\mathrm{p}<0.05)$ for each intervention group, so it can be stated that the implementation of each intervention was significantly effective. the decrease in pain intensity during the first stage of labor in each intervention group. The decrease in maternal pain intensity during the first stage of labor between groups 1, 2 and 3 was significantly different ( $\mathrm{p}<0.05$ ), so it can be said that the effectiveness of the three interventions on reducing pain intensity. measures taken to reduce the intensity of pain during labor, especially the first stage, is to encourage the mother to continue to be able to relax during labor and for the partner or mother's companion to perform counterpressure techniques.
\end{abstract}

Keywords : Relaxation, Stage I, Counterpressure

\begin{abstract}
Abstrak
Nyeri selama proses persalinan berbeda dari nyeri tipe yang lain karena hal tersebut merupakan bagian dari suatu proses normal yang dirasakan saat melahirkan. Para wanita mempunyai waktu untuk mempersiapkannya dan membatasi sendiri nyerinya Untuk mengatasi nyeri digunakan manajemen farmakologis dan nonfarmakologis. Tindakan farmakologis masih menimbulkan pertentangan karena pemberian obat selama persalinan dapat menembus sawar plasenta sehingga dapat mempengaruhi bayi. Oleh karena itu metode pengontrolan nyeri secara nonfarmakologi sangat penting, metode ini dapat membantu mengatasi rasa nyeri dan tidak membahayakan ibu maupun janin, tidak memperlambat persalinan jika diberikan kontrol nyeri yang adekuat, dan tidak mempunyai efek alergi dan efek obat Penelitian ini bertujuan untuk menganalisis efektifitas teknik relaksasi dan counterpressure terhadap penurunan intensitas nyeri selama persalinan kala I di Klinik Nursani Kecamatan Sigumpar Kabupaten Toba Samosir Tahun 2020. Desain yang digunakan dalam penelitian ini adalah Desain yang digunakan dalam penelitian adalah quasy
\end{abstract}


eksperimen jenis One group pretest-posttest yang terdiri dari 3 kelompok dan masing-masing kelompok diberikan intervensi yang berbeda, yang menjadi populasi dalam penelitian ini adalah ibu-ibu bersalin kala I dengan partus pervaginam di di Klinik Nursani Kecamatan Sigumpar Kabupaten Toba Samosir dengan menggunakan accidental sampling. Instrumen yang digunakan kuisioner data demografi dan intensitas nyeri ibu bersalin berdasarkan skala intensitas nyeri intensitas nyeri sebelum dan sesudah intervensi berbeda secara signifikan $(\mathrm{p}<0.05)$ untuk masingmasing kelompok intervensi, sehingga dapat dinyatakan bahwa pelaksanaan masing-masing intervensi ternyata cukup efektif secara signifikan terhadap penurunan intensitas nyeri selama persalinan kala I pada setiap kelompok intervensi. penurunan intensitas nyeri ibu bersalin selama persalinan kala I antara kelompok 1, 2 dan 3 adalah berbeda secara signifikan ( $p<0.05)$, sehingga dapat dikatakan bahwa efektifitas ketiga intervensi terhadap penurunan intensitas nyeri. tindakan yang dilakukan untuk menurunkan intensitas nyeri selama persalinan terutama kala I adalah mendorong ibu untuk tetap dapat melakukan relaksasi selama persalinan dan bagi pasangan ataupun pendamping ibu untuk melakukan teknik counterpressure.

Kata kunci: Relaksasasi, Kala I, Counterpressure

\section{PENDAHULUAN}

Persalinan adalah proses pergerakan keluar janin, plasenta, dan membran janin dari dalam rahim keluar melalui jalan lahir (Bobak, 2004). Proses persalinan identik dengan rasa nyeri yang akan dijalani. Banyak wanita berpikir bahwa nyeri persalinan adalah bagian yang sangat besar yang harus dihadapi dalam persalinan terutama bagi seorang wanita yang baru pertama kalinya bersalin (Januadi, 2002 ).Proses persalinan secara fisiologis dibagi menjadi kala I, kala II, kala III dan kala IV. Persalinan kala I berbeda dari kala persalinan lainnya. Kala I persalinan merupakan fase terlama. Rasa nyeri pada kala I merupakan proses yang fisiologis. Rasa nyeri persalinan kala I disebabkan oleh proses dilatasi serviks, hipoksia otot uterus saat kontraksi, iskemia korpus uteri, peregangan segmen bawah uterus, keadaan mental ibu dan peningkatan prostaglandin sebagai respon terhadap stress. Adanya his atau kontraksi uterus menyebabkan serabut-serabut saraf dan pembuluh darah tertekan. Tekanan pada serabut saraf akan menyebabkan rasa sakit atau nyeri.

Nyeri selama proses persalinan berbeda dari nyeri tipe yang lain karena hal tersebut merupakan bagian dari suatu proses normal yang dirasakan saat melahirkan. Para wanita mempunyai waktu untuk mempersiapkannya dan membatasi sendiri nyerinya.

Cara individu mempersepsikan dan mengatasi nyeri dipengaruhi oleh berbagai faktor. Faktor- faktor tersebut antara lain kecemasan dan ketakutan, kepribadian, kelelahan, budaya dan faktor sosial serta harapan ibu sebelum persalinan (Bennett \& Brown, 1999)

$\begin{array}{rrr}\text { Untuk mengatasi nyeri } & \text { digunakan } \\ \text { manajemen } & \text { farmakologis } & \text { dan }\end{array}$ nonfarmakologis. Tindakan farmakologis masih menimbulkan pertentangan karena pemberian obat selama persalinan dapat menembus sawar plasenta sehingga dapat mempengaruhi bayi. Oleh karena itu metode pengontrolan nyeri secara nonfarmakologi sangat penting, metode ini dapat membantu mengatasi rasa nyeri dan tidak membahayakan ibu maupun janin, tidak memperlambat persalinan jika diberikan kontrol nyeri yang adekuat, dan tidak mempunyai efek alergi dan efek obat.

Sebuah penelitian pada tahun 1998 dengan 4171 wanita sebagai responden didapatkan hasil bahwa $84 \%$ dari wanita tersebut menggunakan metode nonfarmakologi dengan 55,2\% menggunakan teknik relaksasi dan $17,3 \%$ diantaranya menggunakan terapi sentuhan atau sering disebut juga stimulasi kulit. Kedua teknik tersebut merupakan teknik nonfarmakologi yang paling sering digunakan ibu bersalin 
pada umumnya diantara metode nonfarmakologi lainnya.

Teknik relaksasi merupakan metode nonfarmakologi yang paling sering digunakan, efeknya dalam menurunkan nyeri persalinan sebanding dengan penggunaan petidin sebagai metode farmakologi (Mander, 2003). Teknik ini mampu mengurangi kebutuhan tubuh akan oksigen sehingga menurunkan tonus otot, denyut jantung dan tekanan darah.

Teknik stimulasi kulit menjadi alternatif kedua setelah teknik relaksasi dalam mengurangi nyeri persalinan secara nonfarmakologis. Teknik ini mudah dilakukan karena tidak memerlukan keahlian khusus sehingga dapat dilakukan oleh suami atau keluarga, tidak memerlukan biaya yang mahal dan tidak memerlukan peran aktif dari ibu sehingga dapat dilakukan walaupun respon ibu terhadap nyeri berlebihan. Efek terapeutik pada stimulasi kulit didasarkan pada teori nyeri Gate Control. Stimulus kulit berfokus pada permukaan peripheral kulit yang memblok stimulasi nyeri sehingga mengurangi nyeri.

Stimulasi kulit dalam hal ini massage, bisa dilakukan selama persalinan kala I dan efektif mengurangi nyeri. Beberapa teknik massage yang umum adalah effleurage atau pijatan pada abdomen, rubbing atau menggosok bagian tubuh yang nyeri dan counterpressure atau pemberian tekanan pada bagian tubuh yang nyeri.

Banyak wanita menggunakan teknik massage, tapi terkadang mereka hanya menginginkan penekanan pada bagian punggung untuk mengatasi nyeri(Yerry, 2000). Counterpressure merupakan massage tekanan kuat dengan menggunakan tumit tangan atau bagian datar dari tangan, atau juga bola tenis. Stimulus yang diberikan oleh tekanan telapak tangan selain transmisi dari impuls nyeri juga menstimulus endorphin yang merupakan pembunuh nyeri atau pain killer.

Di dalam usahanya untuk mengatasi nyeri persalinan dengan tidak menggunakan metode farmakologi, ibu bersalin pada umumya akan mengkombinasikan teknik- teknik nonfarmakologi. Oleh sebab itu, untuk menurunkan intensitas nyeri terutama pada persalinan kala I, perawat perlu memberikan intervensi-intervensi nonfarmakologi yang baik disertai kerjasama ibu dan pasangannya. Berdasarkan alasan inilah, penelitian ini akan dilakukan untuk meneliti bagaimana efektifitas pengaruh teknik relaksasi dan counterpressure terhadap penurunan intensitas nyeri selama persalinan kala I di Klinik Nursani Kecamatan Sigumpar Kabupaten Toba Samosir Tahun 2020.

\section{METODE PENELITIAN}

Desain yang digunakan dalam penelitian adalah quasy eksperimen jenis One group pretest-posttest yang terdiri dari 3 kelompok dan masing-masing kelompok diberikan intervensi yang berbeda. Populasi penelitian adalah seluruh ibu-ibu bersalin kala I dengan partus pervaginam di di Klinik Nursani Kecamatan Sigumpar Kabupaten Toba Samosir tahun 2020.

Pengambilan sampel dalam penelitian ini menggunakan teknik Accidental sampling. Jumlah sampel yang dibutuhkan sebanyak 21 orang, yang dibagi menjadi 3 kelompok yakni sampel yang diberikan teknik relaksasi, sampel yang diberikan teknik counterpressure, sampel yang diberikan teknik relaksasi yang dikombinasikan teknik counterpressure. Penentuan besar sampel dengan menggunakan tabel power analysis dan ditetapkan (level of significance atau " $\alpha$ ") sebesar 0.05 power sebesar 0.80 dan effect size sebesar 0.35 (Polit \& Hungler, 1995). Penelitian dilaksanakan pada bulan Nopember 2020

\section{HASIL PENELITIAN}

Karakteristik demografi ibu bersalin

Tabel 1. Sebaran karakteristik demografi ibu bersalin.

\begin{tabular}{|c|c|c|c|c|c|c|}
\hline \multirow{2}{*}{$\begin{array}{l}\text { Karakteristik } \\
\text { Demografi Ibu } \\
\text { Bersalin }\end{array}$} & \multicolumn{2}{|c|}{$\begin{array}{c}\text { Kelomp } \\
\text { ok } 1\end{array}$} & \multicolumn{2}{|c|}{$\begin{array}{c}\text { Kelomp } \\
\text { ok } 2\end{array}$} & \multicolumn{2}{|c|}{$\begin{array}{c}\text { Kelomp } \\
\text { ok } 3\end{array}$} \\
\hline & $\mathbf{N}$ & $\%$ & $\mathbf{N}$ & $\%$ & $\mathbf{N}$ & $\%$ \\
\hline \multicolumn{7}{|l|}{ 1. Usia } \\
\hline $21-29$ & 5 & 71.4 & 5 & 71.4 & 4 & 57.1 \\
\hline
\end{tabular}


Cetak ISSN : 2620-5564

Online ISSN : 2655-1292

\begin{tabular}{|c|c|c|c|c|c|c|}
\hline$\geq 30$ & 2 & 28.6 & 2 & 28.6 & 3 & 42.9 \\
\hline \multicolumn{7}{|l|}{ 2. TB (cm) } \\
\hline $145-155$ & 5 & 71.4 & 2 & 28.6 & 3 & 42.9 \\
\hline $156-166$ & 2 & 28.6 & 5 & 71.4 & 4 & 57.1 \\
\hline \multicolumn{7}{|l|}{ 3. BB (kg) } \\
\hline $58-64$ & 1 & 14.3 & 2 & 28.6 & 2 & 28.6 \\
\hline $65-71$ & 6 & 85.7 & 5 & 71.4 & 5 & 71.4 \\
\hline \multicolumn{7}{|l|}{ 4. Paritas } \\
\hline Primipara & 1 & 14.3 & 3 & 42.9 & 4 & 57.1 \\
\hline Multipara & 6 & 85.7 & 4 & 57.1 & 3 & 42.9 \\
\hline \multicolumn{7}{|c|}{ 5. Taksiran berat janin gram) } \\
\hline $2700-3100$ & 4 & 57.1 & 4 & 42.9 & 4 & 42.9 \\
\hline$>3100$ & 3 & 42.9 & 3 & 57.1 & 3 & 57.1 \\
\hline \multicolumn{7}{|c|}{ 6. Hasil Vaginal Tusse (VT) } \\
\hline \multicolumn{7}{|c|}{$\leq 3 \mathrm{~cm}$} \\
\hline \multicolumn{7}{|l|}{$>3 \mathrm{~cm}$} \\
\hline \multicolumn{7}{|c|}{ 7. Usia gestasi (minggu) } \\
\hline $30-34$ & 3 & 42.9 & 3 & 42.9 & 1 & 14.3 \\
\hline$\geq 35$ & 4 & 57.1 & 4 & 57.1 & 6 & 85.7 \\
\hline \multicolumn{7}{|c|}{ 8.Status pekerjaan } \\
\hline Bekerja & 5 & 71.4 & 3 & 42.9 & 2 & 28.6 \\
\hline Tidak & 2 & 28.6 & 4 & 57.1 & 5 & 71.4 \\
\hline \multicolumn{7}{|c|}{ 9. Suku bangsa } \\
\hline Batak & 1 & 14.3 & 2 & 28.6 & 1 & 14.3 \\
\hline Jawa & 3 & 42.9 & 2 & 28.6 & 4 & 57.1 \\
\hline Melayu & 1 & 14.3 & 1 & 14.3 & 1 & 14.3 \\
\hline Lainnya & 2 & 28.6 & 2 & 28.6 & 1 & 14.3 \\
\hline
\end{tabular}

Dari tabel 1 terlihat data hasil penelitian tentang karakteristik ibu bersalin yang diberikan teknik relaksasi saja (kelompok 1), kelompok yang diberikan teknik countepressure saja (kelompok 2) dan kelompok yang diberikan teknik relaksasi yang dikombinasikan dengan teknik counterpressure (kelompok 3).

\section{Intensitas nyeri ibu bersalin sebelum dan sesudah intervensi}

Intensitas nyeri ibu bersalin yang dikaji dengan menggunakan skala nyeri dengan pengelompokan hasil ukur : 0 berarti tidak nyeri, 1-3 nyeri ringan, 4-6 nyeri sedang, 7-9 nyeri berat dan 10 nyeri paling hebat.

Tabel 2. Intensitas nyeri pada Ibu bersalin di Rumah Bersalin Nursani sebelum dan sesudah intervensi.

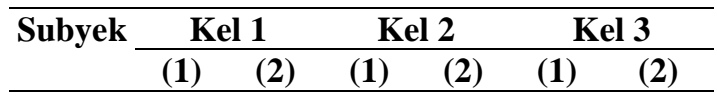

\begin{tabular}{lllllll}
\hline 1. & 7 & 5 & 6 & 5 & 5 & 2 \\
\hline 2. & 4 & 3 & 8 & 7 & 4 & 3 \\
\hline 3. & 7 & 6 & 8 & 6 & 6 & 2 \\
\hline 4. & 5 & 4 & 8 & 7 & 7 & 6 \\
\hline 5. & 5 & 3 & 5 & 2 & 6 & 4 \\
\hline 6. & 3 & 2 & 6 & 5 & 8 & 6 \\
\hline 7. & 5 & 4 & 7 & 6 & 5 & 2 \\
\hline
\end{tabular}

Keterangan tabel :

(1) : Sebelum intervensi

(2) : Sesudah intervensi

Kelompok 1 : Teknik relaksasi saja

Kelompok 2 : Teknik counterpressure

Kelompok 3 : Teknik relaksasi yang dikombinasi dengan teknik counterpressure

Tabel 2 menunjukkan intensitas nyeri sesudah dilakukan intervensi (2) lebih rendah dengan range 3-8 daripada intensitas nyeri sebelum dilakukan intervensi dengan range 2-7(1).

Tabel 3. Gambaran karakteristik intensitas nyeri ibu bersalin di Rumah Bersalin Nursani sebelum dan sesudah intervensi.

\begin{tabular}{lcccccc}
\hline $\begin{array}{l}\text { Kelompok } \\
\text { intervensi }\end{array}$ & \multicolumn{3}{c}{$\begin{array}{c}\text { Intensitas } \\
\text { nyeri sebelum } \\
\text { intervensi }\end{array}$} & \multicolumn{4}{c}{$\begin{array}{c}\text { Intensitas } \\
\text { nyeri sesudah } \\
\text { intervensi }\end{array}$} \\
\cline { 2 - 7 } & Mean & SD Range Mean SD & Range \\
\hline Kelompok & 5.14 & 1.46 & $3-7$ & 3.85 & 1.34 & $2-6$ \\
1 & & & & & & \\
Kelompok & 6.85 & 1.21 & $5-8$ & 5.42 & 1.71 & $2-7$ \\
2 & & & & & & \\
Kelompok & 5.85 & 1.34 & $4-8$ & 3.57 & 1.81 & $2-6$ \\
3 & & & & & & \\
\hline
\end{tabular}

Tabel 3 menunjukkan rata-rata intensitas nyeri ibu bersalin sebelum dan sesudah intervensi pada masing-masing kelompok dimana nilai rata-rata intensitas nyeri sesudah intervensi pada masing-masing kelompok lebih rendah daripada nilai ratarata sebelum intervensi.

Perbedaan intensitas nyeri sebelum dan sesudah intervensi pada masing- masing kelompok intervensi

Untuk mengetahui perbedaan intensitas nyeri sebelum dan sesudah intervensi pada masing-masing kelompok digunakan uji statistik Paired Sample T-Test. 
Tabel 4. Distribusi nilai rata-rata intensitas nyeri pada masing-masing kelompok ibu bersalin di Rumah Bersalin Nursani sebelum dan sesudah intervensi.

\begin{tabular}{lcc}
\hline $\begin{array}{l}\text { Kelompok } \\
\text { Intervensi }\end{array}$ & $\begin{array}{c}\text { Mean } \\
\text { difference }\end{array}$ & Sig. \\
\hline Kelompok 1 & 1.28 & 0.000 \\
Kelompok 2 & 1.42 & 0.003 \\
Kelompok 3 & 2.28 & 0.002 \\
\hline
\end{tabular}

Tabel 4 menunjukkan bahwa intensitas nyeri sebelum dan sesudah intervensi berbeda secara signifikan ( $\mathrm{p}<$ 0.05) untuk masing-masing kelompok intervensi, sehingga dapat dinyatakan bahwa pelaksanaan masing-masing intervensi ternyata cukup efektif secara signifikan terhadap penurunan intensitas nyeri selama persalinan kala I pada setiap kelompok intervensi.

Analisa Perbedaan Penurunan Intensitas Nyeri selama Persalinan Kala I antar Kelompok Intervensi.

Untuk mengetahui perbedaan penurunan intensitas nyeri selama persalinan kala I pada ketiga kelompok intervensi dilakukan dengan menggunakan uji statistik Oneway Anova. Tabel 5 menunjukkan bahwa penurunan intensitas nyeri ibu bersalin selama persalinan kala I antara kelompok 1, 2 dan 3 adalah berbeda secara signifikan ( $\mathrm{p}<$ 0.05), sehingga dapat dikatakan bahwa efektifitas ketiga intervensi terhadap penurunan intensitas nyeri selama persalinan kala I berbeda. Dengan kata lain, ketiga intervensi tersebut tidak sama efektifnya tehadap penurunan intensitas nyeri selama persalinan kala I.

Tabel 5. Distribusi rata-rata penurunan intensitas nyeri ibu bersalin di Rumah Bersalin Nursani pada masing-masing kelompok intervensi.

\begin{tabular}{lcccc}
\hline & Mean & SD & $\begin{array}{c}\mathbf{9 5 \%} \\
\text { CI }\end{array}$ & $\begin{array}{c}\text { P } \\
\text { value }\end{array}$ \\
\hline Kelompok 1 & 4.50 & 1.51 & $3.63-$ & 0.029 \\
& & & 5.37 & \\
Kelompok 2 & 6.14 & 1.61 & $5.21-$ & \\
& & & 7.07 & \\
Kelompok 3 & 4.71 & 1.94 & $3.59-$ & \\
\hline
\end{tabular}

5.83

Rata-rata intensitas nyeri pada kelompok yang diberikan teknik relaksasi saja (kelompok 1) adalah 4.50 dengan standar deviasi 1.51. Pada Kelompok yang diberikan teknik counterpressure saja (kelompok 2) rata-rata intensitas nyeri adalah 6.41 dengan standar deviasi 1.61. Pada kelompok yang diberikan teknik relaksasi yang dikombinasikan dengan teknik counterpressure rata-rata intensitas nyeri adalah 4.71 dengan standar deviasi 1.94 . Hasil uji statistik didapat nilai $\mathrm{p}=0.029$ berarti pada alpha 5\%, dapat disimpulkan ada perbedaan intensitas nyeri diantara ketiga kelompok.

Untuk mengetahui lebih rinci penurunan intensitas nyeri selama persalinan kala I antar kelompok intervensi digunakan statistik Post Hoc Test Multiple Comparisons.

Tabel 6. Post Hoc Multiple Comparisons untuk melihat intensitas nyeri antar kelompok ibu bersalin di Rumah Bersalin Nursani.

\begin{tabular}{lccc}
\hline \multicolumn{1}{c}{$\begin{array}{c}\text { Kelompok } \\
\text { intervensi }\end{array}$} & $\begin{array}{c}\text { Mean } \\
\text { difference }\end{array}$ & Sig. \\
\hline $\begin{array}{l}\text { Kelompok } \\
\text { Kelompok 2 }\end{array}$ & $1-$ & 1.64 & 0.014 \\
$\begin{array}{l}\text { Kelompok } \\
\text { Kelompok 3 } 3\end{array}$ & 0.21 & 0.740 \\
$\begin{array}{l}\text { Kelompok } \\
\text { Kelompok 3 }\end{array}$ & 2- & 1.43 & 0.032 \\
\hline
\end{tabular}

Tabel 6 menunjukkan bahwa kelompok yang berhubungan signifikan adalah kelompok 1 dengan kelompok 2 dan kelompok 2 dengan kelompok 3 sedangkan antara kelompok 1 dan kelompok 3 berbeda tapi tidak signifikan.

Untuk mengetahui intervensi mana yang lebih efektif terhadap penurunan intensitas nyeri selama persalinan kala I digunakan grafik High-low untuk melihat tingkat penurunan intensitas nyeri pada masing-masing kelompok. Dari grafik dapat dilihat bahwa tingkat penurunan intensitas nyeri pada kelompok 3 lebih besar dibandingkan dengan kelompok 1 dan 2, 
sehingga dapat dikatakan bahwa pelaksanaan teknik relaksasi yang dikombinasikan dengan teknik counterpressure memberikan efek yang lebih besar terhadap penurunan intensitas nyeri ibu bersalin selama persalinan kala I dibandingkan dengan kedua kelompok yang lain

\section{PEMBAHASAN}

Ada 3 jenis metode non farmakologi menurut melzack yang saling mempengaruhi repon terhadap nyeri yakni strategi motivasiafektif, kognitif-evaluatif dan sensoridiskriminatif.

Pada penelitian ini, peneliti membandingkan 3 jenis metode penanganan nyeri secara non farmakologi yakni teknik relaksasi yang merupakan salah satu strategi motivasi-afektif dan kognitif-evaluatif, dan teknik counterpressure sebagai strategi sensori-diskriminati, serta kombinasi dari teknik relaksasi dengan teknik counterpressure. Intervensi dilakukan pada kelompok yang berbeda karena ketiga jenis intervensi tersebut merupakan kombinasi strategi atau metode penanganan nyeri secara non farmakologi yang sering dilakukan oleh ibu-ibu bersalin untuk menurunkan intensitas nyeri selama persalinan. Terdapat 21 orang ibu bersalin yang menjadi responden pada penelitian ini dari Rumah Bersalin Nursani Medan.

Berdasarkan hasil penelitian mengenai karakteristik demografi ibu bersalin pada masing-masing kelompok didapati bahwa sebagian besar ibu berusia 21-29 tahun, multipara, dengan taksiran berat janin antara 2700-3500 gram serta usia gestasi > 35 minggu. Ibu-ibu pada penelitian ini sebagian besar adalah suku jawa dan tidak bekerja.

\section{Perbedaan Intensitas Nyeri Ibu Bersalin Sebelum dan Sesudah Intervensi}

Dari hasil pengukuran intensitas nyeri sebelum intervensi diketahui bahwa sebagian besar ibu bersalin mengalami nyeri dengan intensitas nyeri sedang sampai berat dan terdapat perbedaan nilai intensitas nyeri antara ibu bersalin yang satu dengan ibu bersalin lainnya (lihat tabel 2). Hal ini sesuai dengan yang dikemukakan oleh Mc Caffrey bahwa nyeri merupakan pengalaman yang universal dirasakan oleh semua manusia dan bersifat subjektif, sehingga nilainya dapat berbeda dari satu orang dengan orang lain serta bervariasi dirasakan oleh orang yang sama dari waktu ke waktu yang lain, selain itu faktor-faktor yang mempengaruhi nyeri persalinan pada ibu bersalin dapat berbeda antara ibu yang satu dengan ibu lainnya walaupun hasil pemeriksaan vaginal tusse menunjukkan pengukuran yang sama. Faktor-faktor yang mempengaruhi persalinan dapat berupa faktor fisiologis maupun psikologis (Danuatmaja \& Meiliasari, 2004).

Perumus teori nyeri Melzack menyatakan bahwa intensitas nyeri selama persalinan dan melahirkan dapat mencapai angka 8 sampai 10 lebih tinggi dibandingkan back pain, nyeri kanker, nyeri phantom. Wanita nulipara secara umum lebih merasakan nyeri selama awal persalinan sedangkan wanita multipara lebih merasakan nyeri selama akhir kala I dan kala II persalinan sebagai akibat dari penurunan bayi yang cepat (Leeman, 2003).

Intensitas nyeri pada pengukuran yang dilakukan sesudah intervensi pada ibu bersalin didapati bahwa ibu mengalami penurunan intensitas nyeri (lihat tabel 2). Hasil uji statistik menunjukkan bahwa intensitas nyeri sebelum dan sesudah intervensi berbeda secara signifikan $(\mathrm{p}<0.05)$ untuk masing-masing kelompok (lihat tabel 4) sehingga dapat dinyatakan bahwa pelaksanaan masing-masing intervensi cukup efektif terhadap penurunan intensitas nyeri pada ibu bersalin selama persalinan kala I.

Penelitian terdahulu oleh Kimber (2005) didapatkan hasil yaitu ibu yang diberikan stimulasi kulit menyatakan merasakan penurunan nyeri dan kecemasan dan memberikan kenyamanan selama persalinan sedangkan Chamberlain menyatakan $90 \%$ wanita yang mendapatkan teknik relaksasi dan teknik stimulasi kulit (dapat berupa massage ataupun 
counterpressure) mengatakan bahwa teknik tersebut baik untuk menurunkan nyeri.

Dari uraian diatas maka hipotesa penelitian dapat dijawab dimana $\mathrm{H}_{0}$ ditolak dan $\mathrm{H}_{\mathrm{a}}$ diterima karena terdapat pengaruh intervensi teknik relaksasi saja, intervensi teknik counterpressure saja dan pengaruh intervensi teknik relaksasi yang dikombinasikan dengan teknik counterpressure dan adanya penurunan intensitas nyeri persalinan pada ibu selama persalinan kala I pada masing-masing kelompok yang diberikan intervensi berbeda.

\section{Perbedaan Penurunan Intensitas Nyeri selama Persalinan Kala I antar Kelompok.} Berdasarkan perhitungan hasil penelitian dari 21 orang ibu bersalin yang dibagi menjadi 3 kelompok intervensi mengenai penurunan intensitas nyeri ibu bersalin selama persalinan kala I sesudah dilakukan teknik relaksasi saja, teknik counterpressure saja dan teknik relaksasi yang dikombinasikan dengan teknik counterpressure diperoleh nilai signifikansi 0.029 (lihat tabel 5). Hal ini berarti terdapat perbedaan bermakna dalam hal penurunan intensitas nyeri pada ketiga kelompok intervensi. Dengan kata lain, ketiga metode tersebut tidak sama efektifnya terhadap penurunan intensitas nyeri selama persalinan kala I.

Perbedaan penurunan intensitas nyeri ibu bersalin yang paling mencolok adalah antara kelompok 2 dan kelompok 3 yaitu antara kelompok yang diberikan teknik counterpressure saja dan kelompok yang diberikan teknik relaksasi yang dikombinasikan dengan teknik counterpressure.

Penurunan intensitas nyeri yang dirasakan ibu bersalin pada kelompok yang diberikan teknik counterpressure saja dan kombinasi dari teknik relaksasi dan counterpressure didasari oleh adanya faktor psikologis. Penekanan yang dilakukan oleh pendamping ibu baik itu pasangan atau keluarganya memberikan dukungan pada ibu bahwa ia tidak sendirian dalam menghadapi persalinan, hal ini didukung oleh pernyataan
Danuatmaja dan Meiliasari (2004) yang menyatakan bahwa ibu yang melahirkan sendiri tanpa pendamping cenderung merasa takut sehingga ibu merasakan nyeri yang luar biasa selama kontraksi.

Dari hasil penelitian juga diperoleh bahwa penurunan intensitas nyeri ibu bersalin selama persalinan kala I yang terbesar adalah pada kelompok teknik relaksasi yang dikombinasikan dengan teknik counterpressure (lihat grafik High-low).

Penelitian yang dilakukan oleh Linda Kimber terhadap 171 orang dimana 5 wanita nulipara dan 11 wanita multipara yang diberikan teknik relaksasi yang dikombinasikan dengan teknik counterpressure mengalami penurunan intensitas nyeri yang lebih besar dibandingkan dengan ibu bersalin yang hanya diberikan teknik relaksasi saja ataupun ibu yang hanya diberikan teknik counterpressure saja.

Kombinasi dari kedua teknik tersebut yaitu teknik relaksasi berupa latihan pernafasan dengan teknik counterpressure yang merupakan metode stimulasi kulit berupa penekanan pada daerah sakrum dalam menurunkan nyeri ibu selama persalinan kala I cukup efektif karena adanya partisipasi dan kerjasama dari ibu dan pendampingnya (Perry \& Potter, 1993).

Hasil penelitian juga mendukung penelitian sebelumnya bahwa salah satu faktor yang dapat mengurangi adanya trauma persalinan adalah pendamping ibu selama persalinan. Biasanya mereka membutuhkan pendamping yang dapat mendampingi, memberi support, bahkan membantu kelancaran persalinan itu sendiri. Pemberian counterpressure sebagai bentuk dukungan dan komunikasi dari pendamping ibu bahwa ibu tidak sendirian dalam menghadapi persalinan. Penelitian Kimber terhadap 171 ibu bersalin, 21 wanita nulipara dan 16 wanita multipara diantaranya menyatakan bahwa adanya kerjasama dari ibu dengan melakukan teknik relaksasi berupa latihan pernafasan dan counterpressure yang dilakukan pendamping ibu mampu memberikan motivasi bagi ibu untuk 
menghadapi nyeri persalinan yang ditandai dengan adanya peningkatan beta endorphin dalam tubuh ibu (Kimber, 2000).

Kimber dalam penelitiannya juga menyimpulkan bahwa keefektifan metode penanganan nyeri persalinan secara non farmakologi sangat bergantung pada kebutuhannya, fase persalinan yang dilalui dan adanya pendamping yang membantu.

\section{KESIMPULAN}

Kesimpulan hasil penelitian ini yaitu teknik relaksasi dan counterpressure efektif terhadap penurunan intensitas nyeri selama persalinan kala I

\section{SARAN}

1. Bagi pendidikan

Hasil penelitian ini diharapkan menjadi referensi tambahan bagi instansi pendidikan

2. Petugas Kesehatan

Hasil penelitian ini diharapkan menjadi informasi tambahan bagi petugas kesehatan didalam menurunkan nyeri pada persalinan kala 1

\section{REFERENSI}

Benneth \& Brown. (1999). Myles Text Book for Midwifes. London : Harcourt Brace

Bobak, Lowdermilk. (2004). Keperawatan Maternitas. Jakarta : EGC

Danuatmaja \& Meiliasari. (2004). Persalinan normal tanpa rasa sakit. Jakarta : Puspa Swara

Januadi, E. (2002). Mempersiapkan persalinan sehat. Jakarta : Puspa Swara

Kimber, Linda. (2005). Massage Tehniques for Childbirth.

Leeman \& Fontaine. (2003). Management of Labor pain: Promoting patient choice. $\mathrm{www} / \mathrm{http}$ findarticles.com

Mander, Rosemary. (2003). Nyeri Persalinan. Jakarta : EGC
Polit \& Hungler. (1995). Nursing Research $5^{\text {th }}$ edition : Principals and Methods. Philadelphia : JB Lippincott

Perry \& Potter. (1993). Fundamentals of Nursing : Concept, Process \& Practice II $3^{\text {rd }}$ edition. MissouriCalifornia : Mosby Year Book, Inc 